\title{
Peningkatan Keterampilan Menulis Teks Eksposisi Menggunakan Model Problem Based Learning
}

\author{
Martanti Dwi Kristyanawati, Sarwiji Suwandi, Muhammad Rohmadi \\ tantidwi808@gmail.com, sarwijiswan@yahoo.com,rohmadi_dbe@yahoo.com \\ Pascasarjana Pendidikan Bahasa Indonesia, FKIP, Universitas Sebelas Maret Surakarta
}

\section{The Improvement of Expositional Text Writing Skill through Problem-based Learning Model}

\begin{abstract}
The aim of this research is improving expositional text writing skill using PBL for students eighth grade at SMPN 3 Surakarta. PBL is a learning model where the students are asked to solve the problems based on the information given, later they are asked to describe the problems in real life. This Classroom Action Research used the data collection technique with test. The instruments of learning process consisted of 3 items of activity and 20 indicators that were divided into 3 initial stages, core stage, and closing stage. It is shown from the data analysis that the teacher's teaching activity in the first cycle scored 73, in the second cycle scored 77, and the third cycle reached 80, and all those three results achieved 'good' category. The percentage of students' passing level in the first cycle was $43.75 \%$, the second cycle was $68.75 \%$, and the third cycle was $100 \%$. The implementation of PBL was better than in the previous cycle. It was indicated by the improvement in the passing score from $73 \%$ (Classification C) in the second cycle, to $82 \%$ (Classification B)in the third cycle.
\end{abstract}

Keywords: Writing Skill, Problem-Based Learning, CAR, Exposition Text

Received date: 28 Februari 2019

Article Info

Revised date: 6 Mei 2019

Accepted date: 21 Mei 2019

\section{PENDAHULUAN}

Keterampilan menulis merupakan salah satu aspek kebahasaan yang harus dimiliki oleh siswa dalam mengungkapkan ide secara tertulis dan kompleks. Menulis merupakan kegiatan yang sangat rumit dan penuh dengan aturan. Susunan kata-kata, klausa dan kalimat harus terstruktur dan sistematis. Salah satu hal yang berkait rapat dengan keterampilan menulis adalah keterampilan membaca. Dengan membaca, siswa mampu memiliki ide atau konsep secara luas dari suatu permasalahan yang akan ditulis. Setelah itu, siswa harus menguasai tahapan-tahapan menulis untuk mendapatkan hasil yang baik.

Kegiatan menulis pastinya harus diimbangi dengan keaktifan siswa dalam menjalin komunikasi antar guru dan teman sebaya. Salah satu indikator keberhasilan menulis adalah terletak pada hasil tulisan. Untuk itu, siswa harus mengikuti prosedur penulisan sebelum, selama dan setelah penulisan dari guru. Peran guru hanya sebagai fasilitator kelas selama kegiatan berlangsung. Agar mendapatkan hasil yang ingin dicapai maka diperlukan model pembelajaran yang menyenangkan dan menarik perhatian siswa. Model pembelajaran yang memungkinkan siswa terlibat aktif dengan suatu permasalahan (Yew \& Goh, 2016: 2).

Beberapa penelitian yang pernah dilakukan sebelumnya, terdapat beberapa model pembelajaran yang telah diterapkan. Penelitian Rosmaya (2013: 112) pernah menggunakan model pembelajaran berkelompok dengan metode investigasi dalam mengembangkan karangan ekposisi. Ada juga yang menggunakan model sinektik dan model penemuan konsep dalam pembelajaran teks ekposisi (Aztry, 2012: 93). Dua model pembelajaran tersebut memungkinkan siswa untuk terlibat secara aktif dalam proses pembelajaran. Sehingga, fasilitator dapat secara mudah mengajak siswa untuk belajar sekaligus bermain. Namun, tidak semua model pembelajaran dapat diaplikasikan ke semua sekolah dengan latar belakang yang berbeda.

Kenyataannya, permasalahan bermunculan ketika seorang guru menggunakan model pembelajaran yang dinamis. Ada juga yang menggunakan pembelajaran konvensional seperti ceramah atau metode lisan. Hal inilah yang menghambat proses perkembangan siswa dalam menerima atau 
merespon suatu ilmu pengetahuan. Terkadang mereka merasa kesulitan dan ketidakpahaman dalam menguasai materi. Sebenarnya, model pembelajaran itu sama saja, tergantung dari pengguna dan bagaimana fasilitator membuat kenyamanan untuk siswa. Misalnya, siswa yang sedang membuat suatu karangan, fasilitator harus mampu menyesuaikan pendekatan dalam pengembangan suatu ide atau gagasan dalam menyusun kerangka karangan. Dengan ini, siswa akan tampak lebih termotivasi dan bersemangat dalam menuangkan imajinasinya ke dalam petunjuk-petunjuk yang telah diberikan oleh guru.

Dari sini, kami akan menggunakan model pembelajaran berbasis masalah dalam menulis teks ekposisi. Alasannya, model ini sangat berpengaruh pada bagaimana siswa memperoleh solusi dalam memecahkan suatu masalah. Teks ekposisi akan berperan sebagai teks yang memperjelas dan meyakinkan pembaca tentang informasi tertentu. Sehingga, pembaca akan senantiasa memahami dan mengerti bacaan itu tanpa bertanya kepada orang lain. Tujuan pembelajaran $P B L$ ini adalah membimbing siswa dalam menyusun gagasan-gagasan penjelasan berupa informasi dari suatu permasalahan dan menuntut pemahaman pembaca. Maka peneliti akan menggunakan model pembelajaran $P B L$ untuk guru SMP dalam keterampilan menulis teks eksposisi. Problem Based Learning (PBL) merupakan suatu strategi pengajaran yang digunakan oleh guru dengan melibatkan siswa dalam memecahkan suatu masalah. Menurut Wijnia (2016: 1) bahwa pembelajaran berbasis masalah akan memberikan rangsangan pengetahuan dan minat siswa. Cara agar siswa memahami how to learn, how to think and how to live together (Damiyanti, 2006: 108). Untuk itu peneliti menggunakan teori Eggen dan Kauchak dalam pembelajaran menulis teks eksposisi. Teori ini berisi tentang (1) fokus pelajaran dimulai dengan masalah dan pemecahannya; (2) siswa bertanggung jawab untuk merancang strategi dan mencari solusi untuk permasalahan dengan membagi kelompok kecil (biasanya 3 atau 4) sehingga semua siswa terlibat dalam proses; dan (3) guru memandu siswa dari berbagai bentuk pertanyaan dan sanggahan (Eggen \& Kauchak, 2016: 353). Dengan demikian penelitian ini merupakan penelitian terbaru dan belum ada yang meneliti sebelumnya.

\section{KAJIAN PUSTAKA}

Menulis adalah keterampilan yang rumit dan kompleks (Mastan \& Maarof, 2014: 2361). Menurut Fitriyanti \& Setyaningtias (2017: 2), "menulis merupakan membuat huruf (angka dan sebagainya) dengan pena (pensil, kapur, dsb), anak-anak sedang belajar, melahirkan pikiran atau perasaan (seperti mengarang, membuat surat)". Bahkan menulis merupakan suatu kegiatan untuk melaporkan sesuatu yang telah dilakukan. Hasil tulisan pun berbeda-beda, tergantung dari kebutuhan penulis. Agar mendapatkan tulisan yang baik, maka diperlukan langkah-langkah dalam proses penulisan. Dari beberapa teori, tahapan menulis sangat bervariasi, dikutip dari McCrimmon (1972: 3); Mccuen Metherell \& Wincler (2009: 1-4) terdapat tiga tahap proses penulisan antara lain: (1) prewriting (tahap sebelum menulis); (2) writting (tahap menulis); dan (3) rewriting (tahap menulis ulang).

Secara umum proses menulis akan berkait rapat dengan proses penulisan karya ilmiah, pandangan ini telah dikemukakan oleh Grenville dan Sundem. Grenville (2001: 190) memiliki gagasan tentang langkah menulis yang terbagi menjadi enam antara lain: (1) menentukan ide; (2) memilah ide; (3) membuat garis besar; (4) menyusun draf atau kerangka; (5) revisi atau pemeriksaan; (6) editing atau memperbaiki. Lain halnya dengan pendapat Sundem (2007: 42) yang mengelompokkan tujuh langkah menulis, yakni (1) prewriting, (2) drafting, (3) selfrevising (memeriksa secara mandiri), (5) peer/ adult revising (memeriksa dengan rekan/ ahli), (6) editing (perbaikan), (7) publishing (penerbitan). Dua ahli tersebut memiliki tujuan yang sama, hanya saja proses penulisan mempunyai kepentingan dan kebutuhan yang berbeda.

Teks eksposisi merupakan teks yang memaparkan suatu kejadian atau peristiwa secara jelas dan meyakinkan pembaca tentang suatu informasi. Adapun karakter teks ekposisi antara lain: (1) deskripsi obyek yang berkaitan dengan topik; (2) daftar konsep atau ide berdasarkan hubungannya; (3) sebab akibat; (4) perbandingan atau kontras; (5) masalah atau solusi (Lewin, Fine, \& Young, 2001: 4). Menurut Dalman (dalam Dwinuryati, Andayani, \& Winarni (2018: 61), "teks ekposisi bertujuan untuk (1) memberikan informasi mengenai suatu objek; (2) memberitahu, mengupas, menguraikan atau menerangkan sesuatu; (3) menyajikan fakta atau gagasan; dan (4) menjelaskan hakikat sesuatu, memberikan petunjuk untuk mencapai sesuatu. 
Pembelajaran berbasis masalah $(P B L)$ merupakan model pembelajaran yang terfokus pada aktivitas pemecahan permasalahan. Melalui pendekatan $P B L$ diharapkan siswa dapat memiliki keterampilan berpikir secara kreatif dalam memecahkan suatu permasalahan (N \& Anugraheni, 2017: 242). Pembelajaran ini memerlukan suatu grup atau kelompok diskusi, sehingga mereka dapat bertukar pikiran atau gagasan tentang suatu masalah untuk ditemukan solusi yang terbaik. Selain itu, guru sebagai fasilitator kelas memiliki tugas untuk mengatur jalannya kegiatan pembelajaran dengan menggunakan model PBL. Untuk itu diperlukan tahapan yang harus dilakukan dalam pembelajaran berbasis masalah, meliputi (1) mengatur pertanyaan atau masalah (pembelajaran dengan mengatur dan membahas seputar pertanyaan serta menghindari jawaban atau pemecahan masalah yang sederhana); (2) fokus interdisipliner (pembelajaran dengan memusatkan pada subjek tertentu pada masalah yang diselidiki oleh siswa dari berbagai mata pelajaran); (3) investigasi otentik, yakni pembelajaran mengharuskan siswa untuk menemukan suatu keaslian (otentik) dan mencari solusi dari permasalahan yang nyata; (4) menciptakan artefak dan pameran (pembelajaran berbasis masalah mengharuskan siswa untuk menciptakan produk dalam bentuk artefak dan pameran atas dasar pemecahan masalah); (5) kolaborasi adalah pembelajaran berbasis masalah yang saling bekerjasama dan berkelanjutan satu sama lain secara kompleks (Arends, 2012: 397). Sebenarnya sebuah penelitian tentang model pembelajaran melalui kelompok diskusi menggunakan model-model pembelajaran kooperatif seperti NHT dan STAD efektif juga dalam menumbuhkan kompensi siswa dalam pembelajaran (Kusumawati, H., \& Mawardi, M. , 2016: 251), namun penulis ingin mengkonfirmasi keefektifan model pembelajaran PBL, meskipun bukan termasuk rumpun model pembelajaran kooperatif.

\section{METODE PENELITIAN}

Penelitian ini dilaksanakan di SMPN 3 Surakarta pada kelas VIII ${ }^{9}$ semester 1 tahun pelajaran 2018/2019. Penelitian ini berdasarkan proposal yang telah dibuat pada bulan Juli. Siklus pertama dilakukan pada tanggal 12, 19, dan 26 September 2018, siklus kedua dilaksanakan pada tanggal 10, 17, dan 24 Oktober 2018, dan siklus ketiga dilakukan pada tanggal 14, 21, dan 28 November 2018. Subyek penelitian ini adalah seluruh siswa kelas VIII ${ }^{9}$ berjumlah 32 siswa. Sumber data primer berasal dari hasil kegiatan belajar siswa. Untuk memperoleh data tentang hasil belajar siswa maka digunakan teknik tes sebagai teknik pengumpulan data. Instrument kegiatan belajar terdiri dari 3 item kegiatan dan 20 indikator yang terbagi dalam tiga tahapan awal, inti dan penutup. Analisis data yang digunakan dalam penelitian ini adalah untuk mengukur intrumen secara valid atau sah.

Penilaian aktivitas belajar Bahasa Indonesia melalui pendekatan $P B L$ ditentukan berdasarkan kriteria menulis karangan ekposisi yang terdiri dari aspek kohesi dan koherensi (40\%); pengembangan bahasa, mekanik, dan tata tulis (30\%), dan kosa kata (30\%). Hasil pengukuran selanjurnya diklasifikasikan kedalam 4 kategori antara lain: klasifikasi A (Sangat Baik) dengan rentang skor antara 65-80, klasifikasi B (Baik) dengan rentang skor antara 50-64, C (Cukup Baik) dengan rentang skor antara 35-49 dan klasifikasi D (Kurang Baik) dengan rentang skor antara 20-34.

\section{HASIL PENELITIAN DAN PEMBAHASAN Deskripsi Hasil tiap Siklus dan antar Siklus}

Pelaksanaan tindakan siklus I pada pembelajaran Bahasa Indonesia melalui pendekatan pembelajaran Problem Based Learning dilaksanakan pada tanggal 12 dan 19 September 2018 pada jam kedelapan dan kesembilan dalam 2 kali pertemuan (4 x 40 menit). Pertemuan 1 dan 2 digunakan untuk kegiatan pembelajaran, dan pertemuan ke 3 dilaksanakan untuk tes. Pada pertemuan ini peneliti membahas materi menelaah isi dan struktur teks ekposisi dan menyajikan gagasan, pendapat ke dalam bentuk teks ekposisi berupa artikel ilmiah populer.

Pertemuan pertama dilaksanakan pada hari Rabu, 12 September 2018. Adapun kegiatan yang dilaksanakan pada pertemuan pertama diawali dengan kegiatan berdoa sesuai dengan kepercayaan masing-masing. Langkah berikutnya yaitu memberikan apersepsi oleh guru yang meliputi jenis-jenis teks, memberikan pertanyaan tentang jenis-jenis teks, dan guru menampilkan contoh teks ekposisi melalui tayangan media powerpoint. Pada tahap apersepsi, guru bertanya mengenai kendala yang ditemukan siswa dalam menulis teks eksposisi pada tahap pra-tindakan. Hal ini bertujuan agar siswa lebih paham dan mengerti tentang penulisan teks eksposisi yang benar. Dari kesalahan-kesalahan sebelumnya dapat dilihat dalam hal apa siswa masih kurang pengetahuanya dalam menulis teks 
eksposisi. Selanjutnya guru menyampaikan materi tentang teks eksposisi, menjelaskan unsur-unsur teks eksposisi dengan memberikan contoh pada tiap unsur teks eksposisi tersebut, ciri-ciri teks eksposisi, perbedaan teks eksposisi dan jenis teks lainnya serta langkah-langkah apa saja yang dapat dilakukan siswa ketika menulis teks eksposisi dengan memperhatikan fakta dan peristiwa, pilihan kata, tanda baca, dan ejaan.

Guru membagi siswa ke dalam 4 kelompok dengan anggota masing-masing kelompok sebanyak 8 orang siswa. Tiap tim memiliki anggota yang heterogen, baik jenis kelamin, ras, etnik, maupun kemampuannya. Tiap tim membagi anggotanya menjadi dua tim kecil, kemudian menggunakan lembar kerja akademik dan saling membantu untuk menguasai bahan ajar melalui tanya jawab atau diskusi antar sesama anggota tim kecil.

Guru menyajikan contoh teks eksposisi melalui tayangan powerpoint. Siswa diberi tugas untuk membaca contoh teks eksposisi dari media cetak yang sudah disediakan oleh guru. Siswa diberi kesempatan untuk menanyakan hal-hal yang berkaitan dengan ciri, struktur, kaidah yang berkenaan dengan teks eksposisi dan kebahasaannya. Siswa secara berkelompok mengamati, membaca dan memahami contoh permasalahan dari artikel atau teks media cetak yang diberikan oleh guru. Siswa secara berkelompok diberi tugas tentang teks eksposisi misalnya struktur, ciri teks eksposisi, ciri kebahasaan teks eksposisi. Siswa secara berkelompok diberi tugas menuliskan hal-hal yang ditemukan berkenaan dengan struktur, ciri kebahasaan teks eksposisi. Siswa secara kelompok diberi tugas mengidentifikasi definisi, ciri, jenis, struktur, dan kaidah teks penulisan teks eksposisi dari berbagai sumber referensi yang telah dibaca. Siswa secara kelompok diberi tugas menyajikan mengenai identifikasi definisi, ciri, jenis, struktur, dan kaidah teks teks eksposisi dari berbagai sumber referensi yang telah dibaca. Setelah tugas penyajian dilaksanakan, siswa secara kelompok diberi tugas membuat simpulan definisi, ciri, jenis, struktur, dan kaidah teks teks eksposisi dari berbagai sumber. Langkah berikutnya adalah penugasan individual. Siswa secara individu diberi tugas menulis teks eksposisi berdasarkan investigasi dari teks berita di surat kabar. Kegiatan pembelajaran diakhiri dengan guru bersama dengan siswa menyimpulkan hasil pembelajaran yang diperoleh pada hari itu.

Pertemuan kedua pada siklus 1 dilaksanakan hari Rabu, 19 September 2018, Kegiatan tatap muka dimulai dengan siswa dan guru berdoa sesuai dengan agama, dan kepercayaan masing-masing, presensi, apersepsi untuk mengawali pelajaran. Pada kegiatan apersepsi tersebut, guru menyegarkan kembali ingatan siswa tentang penggunaan model Problem Based Learning yang hendak dilaksanakan. Guru membagi siswa ke dalam 4 kelompok dengan anggota masing-masing kelompok sebanyak 8 orang siswa. Sama seperti pertemuan sebelumnya, tiap tim memiliki anggota yang heterogen, baik jenis kelamin, ras, etnik, maupun kemampuannya. Tiap tim membagi anggotanya menjadi dua tim kecil, kemudian menggunakan lembar kerja akademik dan saling membantu untuk menguasai bahan ajar melalui tanya jawab atau diskusi antar sesama anggota tim kecil. Guru menyajikan contoh teks eksposisi melalui tayangan multi-media. Siswa diberi tugas untuk membaca contoh teks eksposisi dari media cetak yang sudah disediakan oleh guru. Siswa diberi kesempatan untuk menanyakan hal-hal yang berkaitan dengan ciri, struktur, kaidah yang berkenaan dengan teks eksposisi dan kebahasaannya.

Siswa mencermati penjelasan guru mengenai teks eksposisi yang meliputi pengertian, struktur, dan kaidah penulisan. Siswa yang sudah benar-benar paham dapat membantu teman kelompoknya yang masih mengalami kesulitan. Setelah semua siswa paham dengan materi pembelajaran, guru memberikan pertanyaan secara acak. Pertanyaan tersebut meliputi materi-materi yang telah dipelajari. Siswa yang bisa menjawab pertanyaan dengan tepat, diberi penguatan dan penghargaan oleh guru. Kuis ini diberikan untuk mengetahui tingkat pemahaman siswa terhadap materi menulis teks eksposisi. Kegiatan selanjutnya yang dilakukan siswa adalah menulis teks eksposisi secara berkelompok. Sebelumnya guru membagikan media berita yang terdapat dalam surat kabar. Semua siswa dalam kelompok harus ikut andil dalam tugas kelompok ini sesuai model investigasi kelompok. Setelah tugas selesai dibuat, guru mengintruksikan tiap-tiap kelompok menukarkan hasil pekerjaannya untuk dikoreksi. Hasil pekerjaan kelompok yang paling baik dipresentasikan di depan kelas untuk dicermati dan dievaluasi bersama-sama. Pada tahap penutup, kegiatan yang dilakukan mencakup (1) siswa bersama guru menyimpulkan hasil kegiatan belajar; (2) guru dan siswa melakukan refleksi tentang kesulitan dalam pembelajaran menulis teks eksposisi; (3) siswa mengisi lembar observasi secara individu sesuai perintah guru; dan (4) tindak lanjut, siswa diberi tugas untuk banyak membaca referensi tentang teks eksposisi. 
Pertemuan ketiga pada siklus pertama dilaksanakan pada hari Rabu, 26 September 2018. Setelah dilakukan obeservasi terhadap kegiatan guru dalam proses pembelajaran, dan aktivitas siswa dalam pembelajaran. Hasil pengamatan menunjukkan bahwa kegiatan guru pada tahap awal pembelajaran baru mencapai tingkat ketercapaian $64.44 \%$ dari ideal, pada tahap inti kegiatan pembelajaran baru mencapai $62.50 \%$ dari skor ideal, dan pada tahap penutup pembelajaran baru mencapai $66.67 \%$ dari skor ideal. Dengan demikian kelemahan guru dalam melaksanakan pembelajaran model Problem Based Learning pada Siklus I terletak pada tahap kegiatan inti pembelajaran. Hasil menunjukkan bahwa aktivitas siswa pada Siklus I masih belum optimal. Belum optimalnya aktivitas siswa dalam pembelajaran terlihat pada hasil pengamatan aspek tahap awal pembelajaran dengan skor ketercapaian sebesar $60.00 \%$ dari ideal, pada tahap inti kegiatan pembelajaran baru mencapai $60.00 \%$ dari skor ideal, dan pada tahap penutup pembelajaran baru mencapai $60.00 \%$ dari skor ideal. Dengan demikian kurang optimalnya keaktifan siswa dalam melaksanakan pembelajaran model Problem Based Learning pada Siklus I terletak pada seluruh tahapan kegiatan pembelajaran yang dilakukan. Keterampilan menulis teks eksposisi diperoleh dari hasil tes akhir Siklus I yang dilaksanakan pada hari Rabu 26 September 2018. Berdasarkan hasil tes yang diperoleh dari 32 orang siswa di kelas VIII.9 menunjukkan bahwa keterampilan menulis pada siswa meningkat dibandingkan dengan kondisi sebelumnya. Hal ini ditunjukkan dengan meningkatnya nilai rata-rata keterampilan menulis yang diperoleh siswa dan ketuntasan belajar siswa dibandingkan dengan kondisi sebelumnya.

Berdasarkan hasil tes akhir Siklus I, dapat diketahui bahwa nilai terendah yang diperoleh siswa adalah sebesar 64.0 dan nilai tertinggi sebesar 83.0, dan nilai rata-rata yang diperoleh adalah sebesar 73.00. Nilai rata-rata kelas yang diperoleh sebesar 73.00 tersebut masih berada di bawah KKM yang ditetapkan dengan $\mathrm{KKM} \geq 75.0$. Atas dasar hal tersebut maka siswa kelas VIII.9 secara klasikal belum mencapai ketuntasan belajar Bahasa Indonesia keterampilan menulis teks eksposisi. Ditinjau dari ketuntasan belajar, dapat diketahui bahwa banyaknya siswa yang sudah mencapai ketuntasan belajar adalah sebanyak 14 siswa atau $43.75 \%$ dari jumlah siswa. Sebagian besar lainnya, yaitu sebanyak 18 siswa atau $56.25 \%$ belum mencapai nilai KKM. Hal ini menunjukkan bahwa tingkat ketuntasan kelas pada siswa kelas VIII. 9 pada Siklus I baru mencapai $43.75 \%$.

Siklus II dilaksanakan mulai minggu ke-2 hingga minggu ke-4 Oktober 2018. Kegiatan dilaksanakan dalam 3 kali pertemuan masing-masing selama 2 x 40 menit (6 x 40 menit). Pertemuan 1 dan pertemuan 2 digunakan untuk kegiatan pembelajaran, sedangkan pertemuan ke 3 digunakan untuk tes. Pertemuan pertama Siklus II dilaksanakan pada hari Rabu, 10 Oktober 2018. Adapun kegiatan yang dilaksanakan pada pertemuan pertama tersebut antara lain meliputi kegiatan-kegiatan sebagai berikut: (a) Kegiatan tatap muka dimulai dengan siswa dan guru berdoa sesuai dengan agama dan kepercayaannya masing-masing, presensi, apersepsi untuk mengawali pelajaran; (b) Guru melakukan apersepsi dengan mengajukan beberapa pertanyaan terkait materi pembelajaran; (c) Guru memberikan motivasi dengan cara menanyakan kepada siswa tentang kegunaan teks eksposisi; (d) Guru menjelaskan tentang tujuan pembelajaran dan penjelasan tentang prosedur pembelajaran yang harus dilakukan; (e) Guru memberi penjelasan tentang penggunaan model Problem Based Learning yang akan dilaksanakan.

Guru membagi siswa ke dalam 6 kelompok dengan anggota masing-masing kelompok sebanyak 5 orang siswa, sehingga ada 2 kelompok yang beranggotakan 6 orang siswa. Setelah siswa dibagi ke dalam kelompok, guru memulai kegiatan inti dengan menyajikan contoh teks eksposisi melalui tayangan multi-media. Siswa diberi tugas untuk membaca contoh teks eksposisi dari media cetak yang sudah disediakan oleh guru. Pada kegiatan ini, siswa diberi kesempatan untuk menanyakan hal-hal yang berkaitan dengan ciri, struktur, kaidah yang berkenaan dengan teks eksposisi dan kebahasaannya. Siswa secara berkelompok mengamati, membaca dan memahami contoh permasalahan dari artikel atau teks media cetak yang diberikan oleh guru. Siswa secara berkelompok diberi tugas untuk dengan teks eksposisi misalnya struktur, ciri teks eksposisi, ciri kebahasaan teks eksposisi. Siswa secara berkelompok diberi tugas menuliskan hal-hal yang ditemukan berkenaan dengan struktur, ciri kebahasaan teks eksposisi. Siswa secara kelompok diberi tugas mengidentifikasi definisi, ciri, jenis, struktur, dan kaidah teks penulisan teks eksposisi dari berbagai sumber referensi yang telah dibaca.

Tahap berikutnya, guru memberikan tugas kelompok kepada siswa untuk menyajikan mengenai identifikasi definisi, ciri, jenis, struktur, dan kaidah teks teks eksposisi dari berbagai sumber referensi yang telah dibaca. Guru berperan sebagai fasilitator pembelajaran. Pada kegiatan akhir pembelajaran, siswa secara kelompok diberi tugas membuat simpulan definisi, ciri, jenis, struktur, dan kaidah teks teks eksposisi dari berbagai sumber. Siswa secara individu diberi tugas menulis teks eksposisi berdasarkan 
investigasi dari teks berita di surat kabar. Kegiatan pembelajaran diakhiri dengan guru bersama-sama dengan siswa menyimpulkan hasil pembelajaran yang diperoleh pada hari itu.

Pertemuan kedua pada siklus II dilaksanakan pada Rabu, 17 Oktober 2018, diawali dengan memberi apersepsi dan mengondisikan siswa dalam bentuk kelompok untuk berdiskusi mengenai materi pertemuan sebelumnya, guru membagikan wacana berita yang terdapat dalam surat kabar kepada masing-masing kelompok. Setelah semua mendapat media tersebut, guru meminta siswa untuk membuat teks eksposisi secara kelompok berdasarkan wacana berita tersebut dengan memerhatikan aspek yang dinilai. Pada siklus II ini, guru lebih menekankan pada kualitas hasil menulis teks eksposisi. Guru juga senantiasa mengingatkan siswa agar kesalahan yang terjadi pada siklus I tidak terulang lagi pada siklus II ini.

Setelah teks eksposisi selesai dibuat oleh siswa, guru meminta setiap kelompok siswa untuk menukarkan hasil pekerjaan mereka dengan kelompok lain untuk dikoreksi. Hal ini bertujuan untuk melatih siswa dalam menilai hasil pekerjaan teman. Selanjutnya, masing-masing kelompok menunjuk perwakilan untuk membacakan hasil pekerjannya di depan kelas. Setelah semua selesai, semua hasil pekerjaan siswa dikumpulkan untuk dikoreksi guru. Dari sini dapat diketahui bagaimana peningkatan keterampilan siswa dalam menulis teks eksposisi pada siklus II.

Pertemuan ketiga pada siklus II dilaksanakan pada hari Rabu 24 Oktober 2018 dengan melaksanakan tes akhir Siklus II. Hasil menunjukkan bahwa kegiatan guru pada tahap awal pembelajaran sudah mencapai tingkat ketercapaian $75.56 \%$ dari skor ideal, pada tahap inti kegiatan pembelajaran sudah mencapai $75.00 \%$ dari skor ideal, dan pada tahap penutup pembelajaran sudah mencapai $80.00 \%$ dari skor ideal. Dengan demikian skor ketercapaian guru dalam melaksanakan pembelajaran model Problem Based Learning pada Siklus II adalah sebesar $76.00 \%$ dari skor ideal. Perolehan tersebut menunjukkan adanya peningkatan dalam kemampuan guru melaksanakan pembelajaran model Problem Based Learning pada Siklus II. Kemampuan guru melaksanakan pembelajaran model Problem Based Learning meningkat dari skor ketercapaian sebesar $64.00 \%$ (klasifikasi D) pada Siklus I, meningkat menjadi sebesar 76.00\% (klasifikasi C) pada Siklus II.

Hasil pengamatan menunjukkan bahwa aktivitas siswa pada Siklus II lebih baik dibandingkan dengan kondisi sebelumnya. Hal ini ditunjukkan dengan perolehan skor sebesar 73 atau dengan ketercapaian sebesar $73.00 \%$ dari skor ideal. Hasil pengamatan terhadap aspek kegiatan pendahuluan atau tahap awal pembelajaran diperoleh skor sebesar 22 atau dengan ketercapaian sebesar $73.33 \%$ dari skor ideal. Hasil pengamatan terhadap aspek kegiatan inti pembelajaran diperoleh skor sebesar 47 atau dengan ketercapaian sebesar $72.31 \%$ dari skor ideal. Hasil pengamatan terhadap aspek kegiatan tahap penutup pembelajaran, diperoleh skor sebesar 4 atau dengan ketercapaian sebesar $80.00 \%$ dari skor ideal. Perolehan tersebut menunjukkan adanya peningkatan dalam aktivitas siswa dalam melaksanakan pembelajaran model Problem Based Learning pada Siklus II. Aktivitas siswa melaksanakan pembelajaran model Problem Based Learning meningkat dari skor ketercapaian sebesar $60.00 \%$ (klasifikasi D) pada Siklus I, meningkat menjadi sebesar 73.00\% (klasifikasi C) pada Siklus II.

Berdasarkan hasil tes akhir Siklus II, dapat diketahui bahwa nilai terendah yang diperoleh siswa adalah sebesar 70.0 dan nilai tertinggi sebesar 87.0, dan nilai rata-rata yang diperoleh adalah sebesar 76.78 (Tuntas). Nilai rata-rata kelas yang diperoleh sebesar 76.78 tersebut sudah melampaui KKM yang ditetapkan dengan $\mathrm{KKM} \geq 75.0$. Atas dasar hal tersebut maka siswa kelas VIII.9 secara klasikal sudah mencapai ketuntasan belajar Bahasa Indonesia keterampilan menulis teks eksposisi. Ditinjau jumlah, dapat diketahui bahwa banyaknya siswa yang sudah mencapai ketuntasan belajar adalah sebanyak 22 siswa atau $68.75 \%$ dari jumlah siswa yang sudah memperoleh nilai $\geq$ KKM. Sebagian lainnya, yaitu sebanyak 10 orang siswa atau $31.25 \%$ belum mencapai nilai KKM. Hal ini menunjukkan bahwa tingkat ketuntasan kelas pada siswa kelas VIII.9 baru mencapai $68.75 \%$.

Siklus III dilakukan pada minggu ke-2 hingga minggu ke-4 November 2018. Siklus III dilakukan dalam 3 (tiga) kali pertemuan. Pertemuan pertama Siklus III dilaksanakan pada Rabu tanggal 14 November 2018. Kegiatan tatap muka dimulai dengan siswa dan guru berdoa sesuai dengan agamadan kepercayaannya masing-masing, presensi, apersepsi, untuk mengawali pelajaran. Kegiatan apersepsi yang dilakukan guru antara lain adalah (1) Menyebutkan jenis-jenis teks; (2) Memberi pertanyaan tentang jenis-jenis teks; dan (3) Guru menampilkan contoh teks eksposisi melalui tayangan multi-media. Langkah yang dilakukan guru selanjutnya adalah pemberian motivasi. Pemberian motivasi dilakukan dengan cara memberikan beberapa pertanyaan yang memancing rasa keingintahuan siswa terhadap materi yang berkaitan dengan pembelajaran yang akan dilaksanakan. Pemberian motivasi 
dilanjutkan dengan penyampaian penjelasan tentang tujuan pembelajaran dan penjelasan tentang prosedur pembelajaran yang harus dilakukan.

Memasuki kegiatan inti pembelajaran, guru memberi penjelasan tentang penggunaan model Problem Based Learning. Guru membagi siswa ke dalam 8 kelompok dengan anggota masing-masing kelompok sebanyak 4 orang siswa. Pada awal tahap inti, guru menyajikan contoh teks eksposisi melalui tayangan multi-media. Siswa diberi tugas untuk membaca contoh teks eksposisi dari media cetak yang sudah disediakan oleh guru. Siswa diberi kesempatan untuk menanyakan hal-hal yang berkaitan dengan ciri, struktur, kaidah yang berkenaan dengan teks eksposisi dan kebahasaannya. Setelah penyampaian penjelasan, guru memberikan tugas kelompok di mana siswa secara berkelompok mengamati, membaca dan memahami contoh permasalahan dari artikel atau teks media cetak yang diberikan oleh guru. Siswa secara berkelompok diberi tugas untuk dengan teks eksposisi misalnya struktur, ciri teks eksposisi, ciri kebahasaan teks eksposisi.

Langkah berikutnya adalah penugasan kelompok. Pada tahap ini, siswa secara berkelompok diberi tugas menuliskan hal-hal yang ditemukan berkenaan dengan struktur, ciri kebahasaan teks eksposisi. Siswa secara kelompok diberi tugas mengidentifikasi definisi, ciri, jenis, struktur, dan kaidah teks penulisan teks eksposisi dari berbagai sumber referensi yang telah dibaca. Siswa secara kelompok diberi tugas menyajikan mengenai identifikasi definisi, ciri, jenis, struktur, dan kaidah teks teks eksposisi dari berbagai sumber referensi yang telah dibaca. Siswa secara kelompok diberi tugas membuat simpulan definisi, ciri, jenis, struktur, dan kaidah teks teks eksposisi dari berbagai sumber. Setelah penugasan kelompok, guru memberikan tugas individu berupa tugas menulis teks eksposisi berdasarkan investigasi dari teks berita di surat kabar. Kegiatan pembelajaran diakhiri dengan guru bersama-sama dengan siswa menyimpulkan hasil pembelajaran yang diperoleh pada hari itu.

Pertemuan kedua Siklus III dilaksanakan pada Rabu tanggal 21 November 2018. Pada kegiatan pendahuluan atau tahap awal dilakukan kegiatan sebagai berikut ini: (a) Kegiatan tatap muka dimulai dengan siswa dan guru berdoa sesuai dengan agama, presensi, apersepsi dan kepercayaan masingmasing, untuk mengawali pelajaran; (b) Guru menyegarkan kembali ingatan siswa tentang penggunaan model Problem Based Learning yang hendak dilaksanakan; dan (c) Guru membagi siswa ke dalam 8 kelompok dengan anggota masing-masing kelompok sebanyak 4 orang siswa.

Pada awal tahap inti, guru menyajikan contoh teks eksposisi melalui tayangan multi-media. Siswa diberi tugas untuk membaca contoh teks eksposisi dari media cetak yang sudah disediakan oleh guru. Siswa diberi kesempatan untuk menanyakan hal-hal yang berkaitan dengan ciri, struktur, kaidah yang berkenaan dengan teks eksposisi dan kebahasaannya. Tahap berikutnya adalah siswa secara berkelompok membahas materi diskusi, menjawab dan memecahkan masalah dan mempresentasikan hasil diskusi di depan kelas. Guru meminta setiap kelompok menyajikan hasil kerja kelompok mereka di depan kelas, sedangkan kelompok lain menanggapi. Pada tahap ini guru berperan sebagai fasilitator pembelajaran. Menjelang akhir kegiatan pembelajaran, guru mendistribusikan kuesioner untuk mengukur motivasi belajar siswa dalam pembelajaran yang dilakukan selama dua kali pertemuan. Kegiatan pembelajaran diakhiri dengan guru bersama-sama dengan siswa menyimpulkan hasil pembelajaran yang diperoleh pada hari itu.

Pertemuan ketiga siklus III dilaksanakan pada Rabu tanggal 28 November 2018. Kegiatan pada pertemuan ketiga ini adalah melaksanakan tes akhir Siklus III. Hasil pengamatan menunjukkan bahwa aktivitas siswa pada Siklus II lebih baik dibandingkan dengan kondisi sebelumnya. Hal ini ditunjukkan dengan perolehan skor sebesar 82 atau dengan ketercapaian sebesar $82.00 \%$ dari skor ideal. Hasil pengamatan terhadap aspek kegiatan pendahuluan atau tahap awal pembelajaran diperoleh skor sebesar 26 atau dengan ketercapaian sebesar $86.67 \%$ dari skor ideal. Hasil pengamatan terhadap aspek kegiatan inti pembelajaran diperoleh skor sebesar 52 atau dengan ketercapaian sebesar $80.00 \%$ dari skor ideal. Hasil pengamatan terhadap aspek kegiatan tahap penutup pembelajaran, diperoleh skor sebesar 4 atau dengan ketercapaian sebesar $80.00 \%$ dari skor ideal.

Berdasarkan hasil tes akhir Siklus III, dapat diketahui bahwa nilai terendah yang diperoleh siswa adalah sebesar 75.0 dan nilai tertinggi sebesar 90.0, dan nilai rata-rata yang diperoleh adalah sebesar 80.22 (Tuntas). Nilai rata-rata kelas yang diperoleh sebesar 80.22 tersebut sudah melampaui $\mathrm{KKM}$ yang ditetapkan dengan $\mathrm{KKM} \geq 75.0$. Atas dasar hal tersebut maka siswa kelas VIII.9 secara klasikal sudah mencapai ketuntasan belajar Bahasa Indonesia keterampilan menulis teks eksposisi. Ditinjau dari jumlah nilai, dapat diketahui bahwa banyaknya siswa yang sudah mencapai ketuntasan belajar dengan $\mathrm{KKM} \geq 75.00$ adalah sebanyak 32 siswa atau 100.00\% dari jumlah siswa. Adapun siswa 
yang belum mencapai KKM sudah tidak ada lagi atau $0.00 \%$. Hal ini menunjukkan bahwa tingkat ketuntasan kelas pada siswa kelas VIII.9 sudah mencapai $100.00 \%$.

Refleksi berfungsi sebagai bahan untuk memantapkan kegiatan pembelajaran yang dilakukan pada siklus III sudah sesuai dengan indikator keberhasilan yang dicapai atau belum. Nilai rata-rata keterampilan menulis pada siswa meningkat dari sebesar 76.78 (Tuntas) pada Siklus II, meningkat menjadi sebesar 80.22 (Tuntas) pada Siklus III. Ketuntasan belajar siswa meningkat dari sebesar $68.75 \%$ pada Siklus II, meningkat menjadi sebesar $100.00 \%$ pada Siklus III. Kegiatan guru dalam melaksanakan pembelajaran model Problem Based Learning lebih baik dibandingkan dengan kondisi sebelumnya. Hal ini diindikasikan dengan meningkatnya skor ketercapaian dari sebesar $76.00 \%$ (klasifikasi C) dari skor ideal pada Siklus II, meningkat menjadi sebesar $88.00 \%$ (klasifikasi A) dari skor ideal pada Siklus III. Aktivitas siswa dalam melaksanakan pembelajaran model Problem Based Learning lebih baik dibandingkan dengan kondisi sebelumnya. Hal ini diindikasikan dengan meningkatnya skor ketercapaian dari sebesar $73.00 \%$ (klasifikasi C) dari skor ideal pada Siklus II, meningkat menjadi sebesar $82.00 \%$ (klasifikasi B) dari skor ideal pada Siklus III.

Setelah melakukan analisa terhadap 3 siklus yang telah dilaksanakan, maka dapat ditarik kesimpulan bahwa penggunaan model pembelajaran $P B L$ dalam materi menelaah isi dan struktur teks ekposisi dan menyajikan gagasan, pendapat ke dalam bentuk teks ekposisi berupa artikel ilmiah populer menunjukkan peningkatan hasil aktivitas belajar Bahasa Indonesia. Berikut ini tabel 1, presentase dan ketuntasan belajar berdasarkan tes keterampilan menulis teks ekposisi Bahasa Indonesia mulai dari prasiklus, siklus I, siklus II, dan siklus III.

Tabel 1. Perbandingan Prosentase dan Ketuntasan Belajar Tes Keterampilan Menulis Teks Eksposisi Kelas VIII SMPN 3 Surakarta

\begin{tabular}{lcccc}
\hline \multicolumn{1}{c}{ Data } & Prasiklus & Siklus I & Siklus II & Siklus III \\
\hline Banyaknya siswa $<$ KKM & 28 & 18 & 10 & 0 \\
\hline Banyaknya siswa $>$ KKM & 4 & 14 & 22 & 32 \\
\hline Prosentase $<$ KKM & $12.50 \%$ & $43.75 \%$ & $68.75 \%$ & $100 \%$ \\
\hline Prosentase $>$ KKM & $87.50 \%$ & $56.25 \%$ & $31.25 \%$ & $0 \%$ \\
\hline Rerata & 63.09 & 73.00 & 76.78 & 80.22 \\
\hline \multirow{2}{*}{ Selisih prosentase } & \multicolumn{3}{c}{$31.25 \%$} & \multicolumn{3}{c}{$31.25 \%$} \\
\cline { 2 - 6 } & \multicolumn{3}{c}{$25 \%$} \\
\hline
\end{tabular}

Dari tabel 1 di atas dapat diperoleh data sebagai berikut: (1) Pra siklus: (a) siswa yang < KKM adalah 28 siswa dengan rerata 63 dan persentase 13\%, (b) siswa yang > KKM adalah 4 siswa memperoleh rerata 63 dengan presentase 88\%; (2) Siklus I: (a) siswa yang < KKM sebanyak 18 siswa dengan rerata 73 dan presentase 44\%, (b) siswa yang > KKM adalah 14 siswa dengan rerata 73 dan presentase 56\%; (3) Siklus II: (a) siswa yang < KKM adalah 10 siswa dengan rerata 77 dan presentase $69 \%$, (b) siswa yang > KKM adalah 22 siswa dengan rerata 77 dan presentase $31 \%$; (3) Siklus III secara keseluruhan siswa memperoleh hasil di atas KKM dengan jumlah 32 siswa dan presentase $100 \%$. Selisih prosentase dari prasiklus dan siklus I adalah $31 \%$, siklus I dan siklus II adalah 25\%, dan siklus II dan siklus III adalah $31 \%$.

\section{Pembahasan}

Dari data perbandingan pada tabel 1, pendekatan $P B L$ telah menunjukkan peningkatan dari siklus I, siklus II, dan siklus III dari hasil observasi kelas VIII ${ }^{9}$ di SMPN 3 Surakarta dalam aktivitas belajar Bahasa Indonesia dari sebanyak 32 siswa telah memenuhi KKM. Selisih peningkatan hasil belajar siswa dari siklus II $68.75 \%$ dan $100 \%$ dari siklus III sebanyak $31.25 \%$. Hal ini sejalan dengan penelitian Rahmah (2018: 99) bahwa adanya perubahan kenaikan prosentase dalam menerapkan pendekatan Problem Based Learning.

Temuan ini bermakna bagi siswa dalam melakukan aktivitas belajar Bahasa Indonesia melalui pendekatan $P B L$ yang berorientasi pada model pembelajaran yang mengutamakan kemampuan memecahkan suatu permasalahan dan keaktifan siswa dalam mencari solusi. Dalam prosesnya, pemecahan masalah melibatkan berbagai sumber belajar yang nantinya diakhiri dengan evaluasi dari informasi yang sudah didapat dari berbagai sumber belajar tersebut agar diperoleh solusi pemecahan masalah yang paling tepat (Mustamilah, 2015: 94). 
Peningkatan Keterampilan Menulis Teks Eksposisi Menggunakan Model Problem Based Learning

(Martanti Dwi Kristyanawati, Sarwiji Suwandi, dan Muhammad Rohmadi)

Hal itu ditegaskan dalam penelitian Son (2017: 259) bahwa "proses pembelajaran dalam PBL, siswa di tuntut untuk mampu bekerja secara kolaboratif untuk mencapai hasil bersama, dimulai dari pendefenisian masalah, kemudian siswa melakukan diskusi untuk menyamakan persepsi tentang permasalahan serta menetapkan tujuan dan target yang harus dicapai dan setelah itu siswa mencari bahan dari sumber-sumber di perpustakaan, internet, melalui personal atau observasi, dengan bantuan guru sebagai fasilitator siswa akan melakukan presentasi untuk menyampaikan hasil diskusi kelompoknya."

Adapun keunggulan dari model pembelajaran Problem Based Learning adalah siswa dapat menemukan permasalahan/ solusi secara mandiri dan kreatif melalui arahan guru dengan suasana yang sangat menyenangkan. Temuan ini sejalan dengan Zamzam (2016: 279) bahwa salah satu keunggulan problem based learning sebagai upaya untuk mengembangangkan berpikir kritis yang berorientasi pada kecakapan siswa memproses informasi.

Peningkatan hasil pembelajaran ini dikarenakan beberapa perihal yang mendukung, selain dari model pembelajaran berbasis masalah yang ditekankan pada interaksi antara guru dan siswa dalam pembelajaran, serta keaktifan siswa dalam memecahkan suatu permasalahan disertai solusi, dimana siswa sebagai subjek pembelajar menjadi lebih bermakna. Dengan pembelajaran secara langsung dalam kehidupan yang nyata, maka siswa akan mudah memahami suatu permasalahan dalam kehidupan sehari-hari untuk menyelesaikannya (Rini \& Mawardi, 2015: 104).

Proses memodifikasi sebagai upaya guru untuk memperoleh situasi yang kondusif dengan model pembelajaran berbasis masalah terhadap materi keterampilan menulis teks eksposisi meningkat dengan presentase $100 \%$ melampaui batas kriteria ketuntasan minimal (KKM) dari ketentuan. Keampuhan model Problem Based Learning mampu meningkatkan keterampilan proses dan hasil belajar siswa. Maka dapat disimpulkan bahwa model Problem Based Learning dapat meningkatkan keterampilan menulis teks eksposisi pada pelajaran bahasa Indonesia siswa kelas VIII ${ }^{9}$ SMPN 3 Surakarta.

\section{SIMPULAN DAN SARAN Simpulan}

Berdasarkan hasil penelitian pada proses pembelajaran bahasa Indonesia materi keterampilan menulis teks eksposisi yang telah dilakukan dengan model pembelajaran Problem Based Learning dapat disimpulkan bahwa siswa lebih aktif dalam bekerjasama antar kelompok. hasil yang diperoleh dari tes pada siklus I diketahui bahwa dari jumlah 32 siswa sebanyak 14 siswa sudah mencapai KKM sedangkan 18 siswa masih belum mencapai KKM. Sehingga persentase ketuntasan $43.75 \%$ dan sisanya $56.25 \%$ belum tuntas dengan rerata 73.00. Dari perbandinan presentase tahapan awal $12.50 \%$ dan presentase siklus I $43.75 \%$ meningkat sebesar $31.25 \%$. akan tetapi, presentase tersebut belum memenuhi KKM sebesar $80 \%$. Maka, penelitian dilanjutkan ke tahap selanjutnya, yaitu siklus II. Pada pelaksanaan proses pembelajaran siklus II rerata hasil belajar siswa meningkat dari 73.00 pada siklus I menjadi 76.78 . Apabila dipresentase selisih dari siklus I 43.75\% dan siklus II 68.75 adalah 25\%. Sebanyak 22 siswa telah memenuhi KKM dan 10 siswa belum memenuhi ketuntasan. Tampak ada peningkatan selisih dari siklus I yaitu $31.25 \%$ menjadi $25 \%$ pada siklus II. Namun, penelitian ini akan dilanjutkan ke tahap selanjutnya untuk mendapatkan hasil yang optimal. Data yang diperoleh dari proses pembelajaran pada siklus III mencapai rerata hasil belajar siswa 80.22 dengan presentase $100 \%$, telah di atas KKM. Peningkatan secara signifikan dan melampaui target KKM 80 yang telah ditentukan. Dari jumlah 32 siswa sebanyak 32 siswa yang telah memenuhi KKM. Selisih peningkatan hasil belajar siswa dari siklus II $68.75 \%$ dan $100 \%$ dari siklus III sebanyak $31.25 \%$.

Penelitian ini dinyatakan berhasil dengan baik karena menunjukkan peningkatan presentase setiap aktivitas dari siklus I, siklus II, dan siklus III. Peningkatan yang terjadi dengan adanya pendekatan Problem Based Learning, siswa secara langsung dapat terlibat dalam menyelesaikan suatu permasalahan yang telah diberikan oleh guru atau fasilitator guru mata pelajaran Bahasa Indonesia di SMPN 3 Surakarta.

\section{Saran}

Penerapan model Problem Based Learning dalam pembelajaran bahasa Indonesia terhadap materi keterampilan menulis teks eksposisi di kelas VIII ini merupakan salah satu dari sekian model pembelajaran yang telah ada. Model pembelajaran Problem Based Learning bukan satu-satunya model 
pembelajaran yang terbaik. Melainkan model pembelajaran Problem Based Learning ini dapat diaplikasikan dalam pembelajaran terhadap kompetensi dasar dalam mata pelajaran bahasa Indonesia atau mata pelajaran lainnya.

Untuk meningkatkan profesionalitas guru, khususnya di SMPN 3 Surakarta dalam meningkatkan kualitas pembelajaran, maka diperlukan kreatifitas guru dalam memilih model pembelajaran yang telah diampu, baik mata pelajaran bahasa Indonesia maupun mata pelajaran lainnya. Selain itu, guru harus melakukan penelitian ulang yang berbeda di sekolah lain dengan subyek yang berbeda pula.

\section{DAFTAR PUSTAKA}

Arends, R. I. (2012). Learning to Teach (Ninth Edit). New York: The McGraw-Hill Companies, Inc.

Aztry, A. (2012). Keefektifan Model Sinektik dan Penemuan Konsep pada Pembelajaran Menulis Puisi Berdasarkan Tingkat Kemandirian Siswa Kelas VII SMP. Seloka : Jurnal Pendidikan Bahasa Dan Sastra Indonesia, 1(2), 91-96.

Damiyanti, M. (2006). Peran Karakteristik Mahasiswa Dalam Pembelajaran Aktif Dengan Sistem PBL. Journal of Dentistry Indonesia, 13(1), 107-110.

Dwinuryati, Y., Andayani, A., \& Winarni, R. (2018). Analisis Kohesi Gramatikal dan Leksikal pada Teks Eksposisi Siswa Kelas 10 Sekolah Menengah Atas. Scholaria: Jurnal Pendidikan Dan Kebudayaan, 8(1), 61-69.

Eggen, P., \& Kauchak, D. (2016). Educational psychology: Windows on Classrooms (Tenth Edit). New York: Pearson Education Limited.

Fitriyanti, R., \& Setyaningtias, E. W. (2017). Pengaruh Metode Chain Writing Terhadap Hasil Belajar Menulis Siswa Kelas 3 Sekolah Dasar. Scholaria: Jurnal Pendidikan Dan Kebudayaan, 7(3), 276-282.

Grenville, K. (2001). Writing from Start to Finish: A Six-Step Guide. Australia: Allen \& Unwin.

Kusumawati, H., \& Mawardi, M. (2016). Perbedaan Penerapan Model Pembelajaran Kooperatif Tipe NHT dan STAD Ditinjau dari Hasil Belajar Siswa. Scholaria: Jurnal Pendidikan dan Kebudayaan, 6(3), 251-263.

Lewin, B. A., Fine, J., \& Young, L. (2001). Expository Discourse: A Genre-Based Approach to Social Research Text. London \& New York: Continuum.

Mastan, M. E., \& Maarof, N. (2014). ESL Learners' Self-efficacy Beliefs and Strategy Use in Expository Writing. Procedia - Social and Behavioral Sciences, 116, 2360-2363.

McCrimmon, J. M. (1972). Writing with a Purpose (Short Edit). United States Of America: Houghton Mifflin.

Mccuen Metherell, J. R., \& Wincler, A. C. (2009). From Idea to Essay: A Rhetoric, Reader, and Handbook. New York: Houghton Mifflin Harcourt Publishing Company.

Mustamilah. (2015). Peningkatan keterampilan proses dan hasil belajar menggunakan model. Scholaria, 5(No.2), 70-79.

N, N. R., \& Anugraheni, I. (2017). Peningkatan Aktivitas Belajar Matematika Melalui Pendekatan Problem Based Learning Bagi Siswa Kelas 4 SD. Scholaria: Jurnal Pendidikan Dan Kebudayaan, 7(3), 241-250.

Rahmah, S. (2018). Peningkatan Hasil Belajar Materi Keunggulan Lokasi Indonesia Melalui Pendekatan Problem Based Learning pada Siswa Kelas VII B SMPN 6 Kota Bima. BRILIANT: Jurnal Riset Dan Konseptual, 3(1), 92-100.

Rini, R., \& Mawardi. (2015). Peningkatan Keterampilan Proses Saintifik dan Hasil Belajar Siswa Kelas 4 SDN Slungkep 02 Tema Peduli Terhadap Makhluk Hidup Menggunakan Model Problem Based Learning. Scholaria: Jurnal Pendidikan Dan Kebudayaan, 5(1), 103-113. 
Peningkatan Keterampilan Menulis Teks Eksposisi Menggunakan Model Problem Based Learning

(Martanti Dwi Kristyanawati, Sarwiji Suwandi, dan Muhammad Rohmadi)

Rosmaya, E. (2013). Pembelajaran Menulis Teks Eksposisi Dengan Menggunakan Pendekatan Kooperatif Tipe Investigasi Kelompok DI SMP. DEIKSIS: Jurnal Pendidikan Bahasa Dan Sastra Indonesia, 5(1), 111-127.

Son, R. S. S. (2017). Pembelajaran Bervisi Sets Model Problem Based Learning Pada Materi Daur Ulang Limbah. Scholaria: Jurnal Pendidikan Dan Kebudayaan, 7(3), 257-266.

Sundem, G. (2007). Practical Strategies for Successful Classrooms: Improving Student Writing Skills. United States Of America: Shell Education.

Wijnia, L. (2016). The Problem With Problems in Problem-Based Learning: Difference Between Problem Explaining Versus Problem Solving. Health Professions Education, 2(2), 59-60.

Yew, E. H. J., \& Goh, K. (2016). Problem-Based Learning: An Overview of its Process and Impact on Learning. Health Professions Education, 2(2), 75-79.

Zamzam, K. F. (2016). Pendekatan Problem Based Learning Untuk Mengembangkan Kemampuan Berpikir Kritis Mahasiswa. Jurnal Pedagogia, 5(2), 279-286. 